\title{
Effects of polymorphisms in the endothelin receptor B subtype 2 gene on plumage colour in mule ducks
}

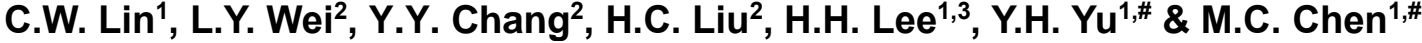 \\ ${ }^{1}$ Department of Biotechnology and Animal Science, National Ilan University, Yilan, Taiwan \\ 2llan Branch, Livestock Research Institute, Council of Agriculture, Yilan 26846, Taiwan \\ ${ }^{3}$ Visiting researcher at National Ilan University
}

(Received 30 September 2019; Accepted 8 April 2020; First published online 18 May 2020)

\author{
Copyright resides with the authors in terms of the Creative Commons Attribution 4.0 South African License. \\ See: http://creativecommons.org/licenses/by/4.0/za \\ Condition of use: The user may copy, distribute, transmit and adapt the work, but must recognize the authors and the South African \\ Journal of Animal Science.
}

\begin{abstract}
The aim of the present study was to investigate the effect of a single nucleotide polymorphism (SNP) of the endothelin receptor $B$ subtype 2 (EDNRB2) gene on plumage coloration in mule ducks. Test mating (white Tsaiya $\times$ white Muscovy ducks) in combination with polymerase chain reaction-restriction fragment length polymorphism (PCR-RFLP) was performed to investigate the effect of non-synonymous SNPs in two maternal lines (a conservation and a selection population) on plumage coloration in mule ducks. One non-synonymous SNP (c.995G>A) was identified in white Muscovy ducks and white Tsaiya ducks by PCR-high-resolution melting (PCR-HRM) and DNA sequencing. Genotyping results showed that the c.995G>A locus is associated with plumage colour in two maternal populations of white Tsaiya ducks. Further, the maternal genotype of c.995G>A SNP affects the plumage colour of mule ducks. Therefore, the polymorphisms within the EDNRB2 gene at c.995G $>A$ in white Tsaiya ducks may be used in marker-assisted selection to improve the plumage colour of mule ducks.
\end{abstract}

Keywords: Muscovy drakes, polymerase chain reaction-restriction fragment length, single nucleotide polymorphism, Tsaiya ducks

\#Corresponding authors: yuyh@niu.edu.tw and mcchen@niu.edu.tw

\section{Introduction}

Animal coats and plumage colour are influenced by melanocyte development, pigment production and pigment distribution (Emaresi et al., 2013). Melanoblasts, the precursors of melanocytes, are derived from neural crest cells. Melanoblasts are able to migrate from the neural crest to the developing feather follicles of the epidermis and then to differentiate into melanocytes (Mills et al., 2009). Several genes have been identified that are involved in melanocyte differentiation, proliferation, migration, and subsequent pigmentation (Roulin \& Ducrest, 2013).

Endothelin receptor B subtype 2 (EDNRB2), a seven-transmembrane domain G-protein-coupled receptor, mainly regulates melanoblast differentiation and migration during melanocyte development (Pla \& Larue 2003; Pla et al., 2005; Harris et al., 2008; Krispin et al., 2010; Nitzan et al., 2013). EDNRB2 expression is maintained throughout the melanocyte lineage (Nataf et al., 1996; Lecoin et al., 1998). Abnormal regulation of the EDNRB2 gene in melanocyte development impairs pigment production and pigment distribution, leading to a white spotting phenotype in animals (Bennett et al., 2003; Miwa et al., 2006; Miwa et al., 2007; Hauswirth et al., 2012; Kinoshita et al., 2014).

Single nucleotide polymorphism variations in the EDNRB2 gene influence plumage colour in avian species (Miwa et al., 2007; Kinoshita et al., 2014; Li et al., 2015; Wu et al., 2017). It has been reported that Cys244Phe and Arg332His amino acid substitutions in the EDNRB2 gene are associated with plumage colour in Japanese native chickens (Kinoshita et al., 2014), Japanese quail (Miwa et al., 2007), and common ducks (Anas platyrhynchos) (Li et al., 2015). In Muscovy drakes (Cairina moschata), the SNPs in EDNRB2 gene that are associated with plumage colour differ from other avian species (Wu et al., 2017). However, little is known about the relationship between EDNRB2 gene polymorphisms and plumage coloration in intergeneric hybrids.

Mule ducks are sterile intergeneric hybrids, which are produced by crossing female common ducks (Anas platyrhynchos) with Muscovy drakes (Cairina moschata). The mule duck is a major meat-type duck in 
Taiwan (accounting for $77 \%$ of duck production) and the white feather colour has economic advantages in comparison with black because of consumer preferences. Since the mule duck is an infertile hybrid, breeding strategies have to be performed on the parental generation, particularly maternal lines. The authors' recent study demonstrated that maternal melanocortin 1 receptor SNP genotypes have a significant influence on white plumage coloration in mule ducks (Tu et al., 2019). Previous studies demonstrated that polymorphisms of EDNRB2 gene are associated with plumage coloration in avian species (Miwa et al., 2007; Kinoshita et al., 2014), including the parental lines of the mule duck (Li et al., 2015; Wu et al., 2017). However, the potential association between EDNRB2 gene and plumage colour phenotypes in intergeneric hybrids such as mule ducks has not been validated. Therefore, the aim of the current study was to analyse the association between the polymorphisms of EDNRB2 gene and plumage colour in mule ducks.

\section{Materials and Methods}

Research on animals was conducted according to the institutional committee on animal use (IACUC Approval No. LRIIL IACUP 105002 and 106004). To identify SNPs of the EDNRB2 gene, blood from six white Tsaiya ducks (conservation population) and six Muscovy drakes were subjected to genomic DNA extraction. Seven primer pairs targeting SNPs of the EDNRB2 gene were evaluated using the high-resolution melting (HRM) assay. Primers were designed based on the exon sequence of the EDNRB2 gene from the common mallard (NCBI reference sequence: KP203838) using Vector NTI 9.1 (Thermo Fisher Scientific, Waltham, MA, USA) software (Table 1). Polymerase chain reaction was performed with G-Storm GS4 thermal cycler (GRI, Rayne, Braintree, UK) and One Taq ${ }^{\circledR}$ polymerase (New England BioLabs, Beverly, MA, USA). The PCR condition was pre-denaturation at $95^{\circ} \mathrm{C}$ for $5 \mathrm{~min}$, followed by 35 cycles of $95{ }^{\circ} \mathrm{C}$ for 30 seconds, $55-64{ }^{\circ} \mathrm{C}$ for 30 seconds, $72{ }^{\circ} \mathrm{C}$ for 30 seconds, and post-elongation at $72{ }^{\circ} \mathrm{C}$ for $7 \mathrm{~min}$. The amplified DNA was melted in the high-resolution melting device (HR-1 instrument, Idaho Technology, Salt Lake City, UT, USA) using LCGreen Plus melting dye (Idaho Technology, Salt Lake City, UT, USA). High-resolution melting curve acquisition was performed from $40{ }^{\circ} \mathrm{C}$ to $95{ }^{\circ} \mathrm{C}$ in $0.2^{\circ} \mathrm{C}$ increments for 1 second, and then normalized with LightScanner Software with CALL-IT 2.0 (Idaho Technology, Salt Lake City, UT, USA). After screening the EDNRB2 gene by HRM analysis, the samples from two ducks with the greatest differences were chosen for further sequencing. The PCR product was purified using the QIAquick PCR purification kit (Qiagen, Valencia, CA, USA) and sequenced with ABI Prism 3700 DNA sequencer (Thermo Fisher Scientific, Waltham, MA, USA). Sequences were analysed with AlignX software (Thermo Fisher Scientific, Waltham, MA, USA) to identify possible polymorphisms.

Table 1 Primer sequence, location and polymerase chain reaction condition of EDNRB2 gene

\begin{tabular}{|c|c|c|c|}
\hline Exon & Primer sequence $\left(5^{\prime} \rightarrow 3^{\prime}\right)^{1}$ & Annealing temperature & Product size \\
\hline \multirow{2}{*}{1} & F: CCATGAGCATCCCAAGGGCT & $60.0^{\circ} \mathrm{C}$ & 777 bp \\
\hline & R: TCGGGAGACTGCAAGTGGCT & & \\
\hline \multirow{2}{*}{2} & F: TTGTTGGACTCTGGCTGCTC & $60.0^{\circ} \mathrm{C}$ & $600 \mathrm{bp}$ \\
\hline & R: CTGAATTTGGCCCAGAACCA & & \\
\hline \multirow{2}{*}{3} & F: ССтСтстGСтсСтGTTGTGT & $58^{\circ} \mathrm{C}$ for Tsaiya ducks; $61^{\circ} \mathrm{C}$ for Muscovy ducks & $389 \mathrm{bp}$ \\
\hline & R: GTGCTTTGCCTAATGCTGCT & & \\
\hline \multirow{2}{*}{4} & F: TGTCGGAGTGGTCTGATGGG & $64^{\circ} \mathrm{C}$ for Tsaiya ducks; $61^{\circ} \mathrm{C}$ for Muscovy ducks & $272 b p$ \\
\hline & R: GGTTTCTGCССTCCTGGCTT & & \\
\hline \multirow{2}{*}{5} & F: CCTGCCCACCTTCTCCTCGC & $60^{\circ} \mathrm{C}$ & $365 \mathrm{bp}$ \\
\hline & R: TGGCCCTGCTGAGAACATTT & & \\
\hline \multirow{2}{*}{6} & F: GTGCTCTTCTGTCTGGTATC & $61^{\circ} \mathrm{C}$ & $357 \mathrm{bp}$ \\
\hline & R: TGATGGGAGTGCCTGGTCTG & & \\
\hline \multirow{2}{*}{7} & F: CСАСАТТTССТССТСТTTCA & $55^{\circ} \mathrm{C}$ & $222 \mathrm{bp}$ \\
\hline & R: TTAGGAAGAGCTGTACTTGT & & \\
\hline
\end{tabular}

${ }^{1} \mathrm{~F}$ : forward primer; R: reverse primer 
Based on sequencing results, PCR-restriction fragment length polymorphism (RFLP) analysis was then used to genotype each SNP in the EDNRB2 gene coding regions in white Tsaiya ducks and mule ducks (Table 2). The enzymatic reactions were performed in $10 \mu \mathrm{L}$ reaction mixtures containing $8 \mu \mathrm{L}$ of PCR products, and two units of each restriction enzyme and reaction buffer. The digested products were separated by $3 \%$ agarose gel electrophoresis and then visualized with ethidium bromide.

Table 2 Detection of EDNRB2 gene polymorphisms by polymerase chain reaction-restriction fragment length polymorphism

\begin{tabular}{|c|c|c|c|c|c|}
\hline SNP & Primer sequence $\left(5^{\prime} \rightarrow 3^{\prime}\right)^{1}$ & $\begin{array}{c}\text { PCR } \\
\text { conditions } \\
\end{array}$ & $\begin{array}{l}\text { PCR product } \\
\text { (bp) }\end{array}$ & $\begin{array}{c}\text { Restriction } \\
\text { enzyme }\end{array}$ & Allele size (bp) \\
\hline \multirow[t]{2}{*}{ c. $273 C>G$} & F:CCATGAGCATCCCAAGGGCT & $\begin{array}{l}94^{\circ} \mathrm{C} 30 \mathrm{~s}, \\
58^{\circ} \mathrm{C} 30 \mathrm{~s}, \\
72^{\circ} \mathrm{C} 40 \mathrm{~s}\end{array}$ & \multirow[t]{2}{*}{385} & \multirow[t]{2}{*}{ Rsal } & C: $183,138,64$ \\
\hline & R:AGGAGCGTGGAGTTGCCGAT & 35 cycles & & & G:183, 202 \\
\hline \multirow[t]{2}{*}{ c.706delins ${ }^{2}$} & F:CCTGTTGGTGGCTCTTCTCA & $\begin{array}{l}94^{\circ} \mathrm{C} 30 \mathrm{~s}, \\
55^{\circ} \mathrm{C} 30 \mathrm{~s}, \\
72^{\circ} \mathrm{C} 40 \mathrm{~s}\end{array}$ & \multirow[t]{2}{*}{255} & \multirow[t]{2}{*}{ Rsal } & $1^{3}: 61,147,47$ \\
\hline & R:GCTGGATTTCTGCTCGGAGG & 35 cycles & & & $D^{4}: 61,194$ \\
\hline \multirow[t]{2}{*}{ c. $995 \mathrm{G}>\mathrm{A}$} & F:СCTGCCCACCTTCTCCTCGC & $\begin{array}{l}94^{\circ} \mathrm{C} 30 \mathrm{~s}, \\
60{ }^{\circ} \mathrm{C} 30 \mathrm{~s}, \\
72^{\circ} \mathrm{C} 40 \mathrm{~s}\end{array}$ & \multirow[t]{2}{*}{365} & \multirow[t]{2}{*}{ SfaNl } & G:104, 31, 230 \\
\hline & R:TGGCCCTGCTGAGAACATTT & 35 cycles & & & $A: 135,230$ \\
\hline
\end{tabular}

For test mating, fifteen female white Tsaiya ducks (Anas platyrhynchos) from a conservation population (18th generation of a natural mating programme without selection) and 19 female white Tsaiya ducks from a selection population (30th generation of a programme that selected for plumage colour using traditional phenotype-based estimated breeding) were mated by artificial insemination with pooled semen from three white Muscovy drakes (Cairina moschata). This mating experiment was part of the authors' previous study (Tu et al., 2019). The plumage colour of the mule ducks was graded based on the area of black spots on the head and back according to a previous study (Lee \& Kang, 1997; Tu et al., 2019). Grades 1 to 3 indicated ducks with a black spot on the head; 4 to 7 indicated ducks with a black head and a little spot on the back; 8 to 10 indicated ducks with a black head, black back and black tail; and 11 to 15 indicated ducks from a mottled coat to pure black. Venous blood and tissue samples were collected from maternal lines (Tsaiya ducks) and intergeneric hybrid ducks mule ducks, respectively. The genomic DNA was extracted using a standard phenol/chloroform method and the concentration of purified DNA was measured with a spectrophotometer (NanoVue PlusTM, GE Healthcare, UK). Stock DNA samples were then stored at $-20{ }^{\circ} \mathrm{C}$ for analysis of polymorphisms of the EDNRB2 gene.

Each duck formed an experimental unit for the association analysis of the EDNRB2 SNP with plumage colour. Chi-square test $\left(\mathrm{X}^{2}\right)$ was used to determine a significant difference in potential associations between EDNRB2 SNP and plumage colour using SAS software (version 9.2.). Chi-square test of independence was performed following null and alternative hypotheses $\mathrm{H} 0$ (independent, no association) and $\mathrm{H} 1$ (not independent, association), respectively. The formula of chi-square test was:

$$
\chi^{2}=\sum \frac{(o-e)^{2}}{e} \text { with degrees of freedom }(r-1)(c-1)
$$

Where $o$ and $e$ represent observed and expected frequency, and $r$ and $c$ are the number of rows and columns 
of the contingency table. $P$ values lower than 0.05 were considered statistically significant. The effect of maternal lines and c.995G>A SNP on plumage colour grading in mule ducks was analysed using one-way ANOVA through the general linear model (GLM) procedure in SAS software (version 9.2.). The means of plumage colour grading were compared with the Tukey test when the probability values were significant $(P$ $<0.05)$.

\section{Results and Discussion}

The grading results demonstrated that the plumage colour grading of mule ducks produced from a selection population was lower than the conservation population (Table 3).

Table 3 Plumage colour grading of mule ducks produced from conserved and selected populations of maternal Tsaiya ducks

\begin{tabular}{|c|c|c|c|}
\hline & Conservation & Selection & $P$-value \\
\hline Plumage colour grading ${ }^{1}$ & $9.1 \pm 3.5^{\mathrm{a}}$ & $2.3 \pm 0.9^{b}$ & $<0.001$ \\
\hline Number of mule ducks & 57 & 121 & \\
\hline
\end{tabular}

Values are expressed as mean \pm SD

${ }^{1}$ Plumage colour grading: 1 - 3 indicated ducks with black spots on head; 4 - 7 indicated ducks with black spots on head, and a little spot on back; 8 - 10 indicated ducks with black spots on head, back, and tail; 11 - 15 indicated ducks from a mottled coat to pure black

a-bMeans within the same row with different superscripts are significantly different $(P<0.05)$.

After screening with HRM analysis and sequencing, twelve synonymous SNPs and one non-synonymous SNP (c.995G>A, p.Arg332His) were detected in the EDNRB2 gene of Tsaiya ducks from the conservation population (Table 4). Of the eight SNPs located in the EDNRB2 gene of Muscovy drakes, five SNPs were synonymous, one was an insertion/deletion variation (c.706delins), one was nonsense variation (c.273C>G, p.Tyr91stop codon) and one led to amino acid substitution (c.995G>A, p.Arg332His) (Table 4).

The c.273C>G SNP in female Tsaiya ducks showed a homozygous genotype CC in both populations, indicating that the maternal line was monomorph for the $C$ allele. To further study the paternal effect of c.273C>G SNP on plumage colour grading, the pooled semen from Muscovy drakes containing genotype GC and CC in the c.273 SNP locus (Table 4) was mated with female conserved Tsaiya ducks. The results showed that black plumage in mule ducks, which were produced by crossing conserved female Tsaiya ducks with Muscovy drakes, displayed a predominantly CC genotype of c.273C>G SNP (Table 5). However, the mule ducks with GC genotype of c.273C>G SNP did not show a differential plumage colour (Table 5), indicating that no significant association between c.273C>G SNP and plumage colour was found in mule ducks. Similar to c.273C>G SNP, c.706delins SNP in female Tsaiya ducks showed a homozygous genotype DD (deletion mutations) in both the conservation population and selection population, indicating that the female population was monomorph for the $D$ allele. Muscovy drakes contain genotype DI (deleted and insertion mutations) and DD in c.706delins SNP locus (Table 4). To examine the paternal effect of c.706delins SNP on plumage colour grading, the pooled semen from Muscovy drakes was mated with female conserved Tsaiya ducks. The results revealed that black plumage in mule ducks displayed a predominant DI genotype of c.706delins SNP, while no distinct plumage colour distribution was found in mule ducks with DD genotype of c.706delins SNP (Table 5). These findings demonstrate that c.706delins SNP in mule ducks was not associated with plumage colour. 
Table 4 Polymorphisms of EDNRB2 gene in Tsaiya ducks and Muscovy drakes

\begin{tabular}{|c|c|c|c|c|c|}
\hline Breed $^{1}$ & $\begin{array}{l}\text { cDNA } \\
\text { position }\end{array}$ & $\begin{array}{c}\text { Nucleotide } \\
\text { polymorphism }\end{array}$ & Codon change & Amino acid polymorphism & Property change \\
\hline $\mathrm{T}$ & 30 & $\mathrm{~T}>\mathrm{C}$ & $\mathrm{CTT}>\mathrm{CTC}$ & $(\mathrm{Val} / \mathrm{V})$ & -2 \\
\hline $\mathrm{T}$ & 57 & $C>T$ & $\mathrm{TCC}>\mathrm{TCT}$ & (Ser/S) & - \\
\hline $\mathrm{T}$ & 219 & $A>G$ & $\mathrm{CCA}>\mathrm{CCG}$ & (Pro/P) & - \\
\hline $\mathrm{T}$ & 348 & $C>T$ & $\mathrm{TAC}>\mathrm{TAT}$ & $(\operatorname{Tyr} / Y)$ & - \\
\hline $\mathrm{T}$ & 354 & $C>T$ & AAC $>A A T$ & $($ Asn $/ \mathrm{N})$ & - \\
\hline $\mathrm{T}$ & 402 & $\mathrm{~T}>\mathrm{C}$ & СТT $>$ CTC & (Leu/L) & - \\
\hline $\mathrm{T}$ & 454 & $C>T$ & CTG $>$ TTG & (Leu/L) & - \\
\hline $\mathrm{T}$ & 543 & $G>T$ & CTG $>$ CTT & (Leu/L) & - \\
\hline $\mathrm{T}$ & 810 & $\mathrm{~T}>\mathrm{C}$ & TAT>TAC & $(\mathrm{Tyr} / \mathrm{Y})$ & - \\
\hline $\mathrm{T}$ & 861 & $\mathrm{~T}>\mathrm{C}$ & TGT $>$ TGC & (Cys/C) & - \\
\hline $\mathrm{T}$ & 868 & $\mathrm{~T}>\mathrm{C}$ & TTG $>$ CTG & (Leu/L) & - \\
\hline $\mathrm{T}$ & 903 & $\mathrm{~T}>\mathrm{C}$ & AAT $>$ AAC & $(A s n / N)$ & - \\
\hline $\mathrm{T}$ & 995 & $G>A$ & $C G C>C A C$ & CGC $(\mathrm{Arg} / \mathrm{R})>\mathrm{CAC}(\mathrm{His} / \mathrm{H})$ & basic \\
\hline$M$ & 273 & $C>G$ & TAC>TAG & $\mathrm{TAC}(\mathrm{Tyr} / \mathrm{Y})>\mathrm{TAG}(\mathrm{X})$ & aromatic>stop codon \\
\hline M & 402 & $\mathrm{~T}>\mathrm{C}$ & CTT>CTC & $($ Leu/L) & - \\
\hline M & 510 & $G>A$ & $C A G>C A A$ & $(G \ln / Q)$ & - \\
\hline M & 706 & indels $^{3}$ & multiple variation & & \\
\hline M & 942 & $G>A$ & GTG>GTA & $(\mathrm{Val} / \mathrm{V})$ & - \\
\hline$M$ & 995 & $G>A$ & $C G C>C A C$ & $\operatorname{CGC}(\mathrm{Arg} / \mathrm{R})>\mathrm{CAC}(\mathrm{His} / \mathrm{H})$ & basic \\
\hline M & 1011 & $C>T$ & $\mathrm{ACC}>\mathrm{ACT}$ & $(\operatorname{Thr} / \mathrm{T})$ & - \\
\hline M & 1077 & $C>T$ & TTC $>$ TTT & (Phe/F) & - \\
\hline
\end{tabular}

${ }^{1} \mathrm{~T}$ : Tsaiya duck; M: Muscovy drake

${ }^{2} \mathrm{~A}$ dash symbol (-) indicates that no amino acid property change occurred

${ }^{3}$ Insertion or deletion mutations occurred in exon 3 of EDNRB2 gene

Table 5 Association of plumage colour grading and EDNRB2 genotype (c. $273 C>G$ and c.706delins) in mule ducks produced by crossing conserved female Tsaiya ducks with Muscovy drakes

\begin{tabular}{|c|c|c|c|c|}
\hline \multirow{3}{*}{$\begin{array}{l}\text { Plumage colour grading } \\
\text { of the mule duck }\end{array}$} & \multirow[b]{3}{*}{ Total } & \multicolumn{2}{|c|}{ c. 273} & \multirow{3}{*}{ Chi-square } \\
\hline & & \multicolumn{2}{|c|}{ Genotype } & \\
\hline & & $\mathrm{C} / \mathrm{C}$ & $\mathrm{G} / \mathrm{C}$ & \\
\hline $1-3$ & 4 & 0 & 4 & \\
\hline $4-7$ & 14 & 1 & 13 & \\
\hline $8-10$ & 13 & 5 & 8 & \\
\hline $11-14$ & 26 & 5 & 21 & $2.79^{\mathrm{a}}$ \\
\hline \multirow{3}{*}{$\begin{array}{l}\text { Plumage colour grading } \\
\text { of the mule duck }\end{array}$} & \multicolumn{3}{|c|}{ c.706indels } & \multirow{3}{*}{ Chi-square } \\
\hline & & \multicolumn{2}{|c|}{ Genotype } & \\
\hline & Total & $\mathrm{D} / \mathrm{D}$ & $\mathrm{D} / \mathrm{l}$ & \\
\hline $1-3$ & 4 & 4 & 0 & \\
\hline $4-7$ & 14 & 12 & 2 & \\
\hline $8-10$ & 13 & 8 & 5 & \\
\hline $11-14$ & 26 & 20 & 6 & $1.51^{\mathrm{a}}$ \\
\hline
\end{tabular}


All the genotypes identified in male Muscovy drakes were GG for c.995G>A SNP, indicating that the male population was monomorph for the $G$ allele. As expected, a normal genotype distribution and allele frequency of c.995G $>A$ SNP were observed in the conservation population (Table 6 ). In the selection population, maternal c.995G>A SNP showed a homozygous genotype AA for the advantageous white plumage coloration in their offspring compared with the conservation population (Table 6).

Table 6 Genotype and allele frequency of c.995 EDNRB2 gene in Tsaiya ducks

\begin{tabular}{|c|c|c|c|c|c|c|c|c|}
\hline \multirow{2}{*}{ SNP } & \multirow{2}{*}{ Maternal line } & \multirow{2}{*}{ Number } & \multicolumn{3}{|c|}{ Genotype frequency } & \multicolumn{2}{|c|}{ Allele frequency } & \multirow{2}{*}{ Chi-square } \\
\hline & & & GG & GA & AA & $\mathrm{G}$ & $A$ & \\
\hline \multirow{2}{*}{ c.995 } & Conservation & 15 & $0.27(4)$ & $0.53(8)$ & $0.20_{(3)}$ & 0.53 & 0.47 & \\
\hline & Selection & 19 & $0.00_{(0)}$ & $0.00_{(0)}$ & $1.00_{(19)}$ & 0.00 & 1.00 & $18.15^{\mathrm{a}}$ \\
\hline
\end{tabular}

${ }^{\mathrm{a} C h i-s q u a r e ~ t e s t ~ c o m p a r i n g ~ g e n o t y p i c ~ f r e q u e n c i e s ~ o f ~ t h e ~ c o n s e r v a t i o n ~ a n d ~ s e l e c t i o n ~ p o p u l a t i o n ~}$

Test mating results demonstrated that the c.995G>A SNP in mule ducks produced by crossing conserved female white Tsaiya ducks with Muscovy drakes showed a genotype GA for advantage of low plumage colour grading, while mule ducks with genotype GG tended to have a higher plumage colour grading $(P<0.05)$ (Table 7). Furthermore, the authors examined the effect of parental genotypes of c.995G>A SNP on plumage colour in mule ducks (Table 8). As expected, c.995G>A SNP in mule ducks produced by crossing selected female Tsaiya ducks with Muscovy drakes showed a genotype GA for the advantage of white plumage colour (grading 2.3) $(P<0.05)$, whereas mule ducks produced by crossing conserved female Tsaiya ducks with Muscovy drakes showed a genotype GG for the advantage of black plumage colour (grading range from 11.4 to 12.3) $(P<0.05)$ (Table 8 ). The genotype GA of mule ducks produced by crossing conserved female Tsaiya ducks with Muscovy drakes showed a reduced plumage colour grading (average grading 6.85) compared with genotype GG of mule ducks (grading range from 11.4 to 12.3) $(P<0.05)$ (Table 8 ), indicating that $A$ allele from parental generation contributed to determine the white plumage colour in mule ducks.

Table 7 Association of plumage colour grading and EDNRB2 genotype (c.995G>A) in mule ducks produced by crossing conserved female Tsaiya ducks with Muscovy drakes

\begin{tabular}{|c|c|c|c|c|}
\hline \multirow{3}{*}{$\begin{array}{l}\text { Plumage colour grading of the } \\
\text { mule duck }\end{array}$} & \multirow[b]{3}{*}{ Total } & \multicolumn{2}{|c|}{ c.995 } & \multirow[b]{3}{*}{ chi-square } \\
\hline & & \multicolumn{2}{|c|}{ Genotype } & \\
\hline & & $\mathrm{G} / \mathrm{G}$ & $\mathrm{G} / \mathrm{A}$ & \\
\hline $1-3$ & 4 & 0 & 4 & \\
\hline $4-7$ & 14 & 0 & 14 & \\
\hline $8-10$ & 13 & 6 & 7 & \\
\hline $11-14$ & 26 & 20 & 6 & $20.85^{a}$ \\
\hline
\end{tabular}

${ }^{a}$ Chi-square test comparing plumage colour grading and genotype

In this study, the authors demonstrated for the first time that maternal SNP variations in EDNRB2 gene are associated with the plumage colour of intergeneric hybrid ducks. They demonstrated that one nonsense variation (c.273C $>\mathrm{G}$ ) and one insertion/deletion variation (c.706delins) were identified in Muscovy ducks and one non-synonymous SNP (c.995G>A) was identified in Muscovy ducks and Tsaiya ducks. Further, the parental genotype of c.995G>A SNP in EDNRB2 gene significantly affected the plumage colour of mule ducks. 
Table 8 Association of maternal genotype of EDNRB2 (c.995G>A) and plumage colour grading of mule ducks

\begin{tabular}{|c|c|c|c|c|}
\hline \multirow{2}{*}{ Maternal line } & \multicolumn{2}{|c|}{ Parental genotype of c. $995 \mathrm{G}>\mathrm{A}$} & \multicolumn{2}{|c|}{ Mule duck } \\
\hline & Muscovy drake & Tsaiya duck & Genotype & Colour grading \\
\hline \multirow{4}{*}{ Conservation } & \multirow{4}{*}{ GG } & GG & $G G(n=15)$ & $11.4 \pm 1.1^{\mathrm{a}}$ \\
\hline & & \multirow{2}{*}{ GA } & $G G(n=11)$ & $12.3 \pm 1.4^{\mathrm{a}}$ \\
\hline & & & $\mathrm{GA}(\mathrm{n}=21)$ & $6.9 \pm 3.3^{b}$ \\
\hline & & AA & $\mathrm{GA}(\mathrm{n}=10)$ & $6.8 \pm 2.7^{b}$ \\
\hline Selection & GG & AA & $\mathrm{GA}(\mathrm{n}=121)$ & $2.3 \pm 0.9^{c}$ \\
\hline$P$-value & & & & $<0.001$ \\
\hline
\end{tabular}

Values are expressed as mean $\pm \mathrm{SD}$

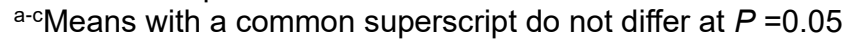

Japanese quail with 'panda' plumage (white coat with a few pigmented spots on the head and back) had a predominantly AA genotype of c.995G>A SNP, while wild-type plumage had a predominantly GG genotype of c.995G>A SNP (Miwa et al., 2007). The nucleotide position 995, a non-synonymous SNP (c.995G $>$ A) in the EDNRB2 gene, results in an arginine to histidine change at amino acid position 332 (Arg332His) (Miwa et al., 2007). Similarly, the Arg332His amino acid substitution (AA genotype of c.1272G>A $\mathrm{SNP}$ ) in EDNRB2 gene of chickens tended towards the mottled plumage phenotype (white coat with pigmented spots on the head) (Kinoshita et al., 2014). Furthermore, domestic ducks with spot phenotype (white coat with a few pigmented spots on the back) displayed a predominantly AA genotype of c.995G>A SNP, while non-spot phenotype (black plumage) displayed a predominantly GG genotype of c.995G>A SNP (Li et al., 2015). Consistently, the authors found that white plumage in Tsaiya ducks from the selection population displayed a predominantly AA genotype of c.995G >A SNP. These findings indicate that an arginine to histidine change at amino acid position 332 (Arg332His) in EDNRB2 gene is associated with pigment distribution and results in a white plumage phenotype in avian species.

Over the past few years, only two studies have reported findings on the association between the polymorphism of EDNRB2 gene and plumage colour in duck species (Li et al., 2015; Wu et al., 2017). It has been reported that the domestic ducks (Anas platyrhynchos) from a cross between white Kaiya and the white Liancheng duck with spot phenotype displayed predominant AA genotype of c.995G>A SNP (Li et al., 2015). The current result is consistent with the previous finding that AA genotype of c.995G >A SNP in Tsaiya ducks (Anas platyrhynchos) from a selection population is associated with white plumage colour. The authors further demonstrated that white plumage in mule ducks displayed predominant GA genotype of c.995G>A SNP. These results imply that maternal $A$ allele from Tsaiya ducks highly influences white plumage coloration in its offspring. Whether the paternal A allele from Muscovy drakes also has an impact on white plumage coloration in its offspring remains to be elucidated. However, no similar SNPs and amino acid substitutions were found in EDNRB2 gene in domestic ducks (Anas platyrhynchos) and Muscovy drakes (Wu et al., 2017). These findings indicate that the EDNRB2 gene polymorphism that has associated with plumage colour in Muscovy drakes is completely different from domestic ducks (Li et al., 2015).

The expression of EDNRB2 mRNA from non-pigmented skin of chickens with mottled plumage (Arg332His) is decreased compared with the pigmented skin of chickens with mottled plumage (Kinoshita et al., 2014). Similarly, EDNRB2 mRNA levels from the skin of Japanese quail with panda plumage (Arg332His) are decreased compared with birds with wild-type plumage (Miwa et al., 2007). These results imply that the regulation of EDNRB2 mRNA expression is critical for pigmentation in the skin. However, no significant difference was found in EDNRB2 mRNA expression between the white and black feather bulbs of domestic ducks (Li et al., 2012). Therefore, whether the AA genotype of c.995G>A SNP in Tsaiya ducks and GA genotype of c.995G>A SNP in mule ducks correlate with EDNRB2 mRNA levels in skin needs further study.

In this study, the authors demonstrated that maternal A allele of c.995G>A SNP from a selection or conservation population is a critical factor in the plumage colour of mule ducks. Mule ducks with GA genotype of c.995G>A SNP, which is produced by crossing selected female Tsaiya ducks and Muscovy drakes, displayed a low plumage colour grading (Grading 2.3). However, mule ducks with GA genotype of c.995G $>A$ SNP that were produced by crossing conserved female Tsaiya ducks and Muscovy drakes displayed a middle plumage colour grading (grading ranged from 6.8 to 6.9). Several plumage colour mutants of ducks are produced by the combined effect of controlled breeding and selection pressures from domestication (Gong et 
al., 2010). Taken together, these findings imply that other SNPs that are associated with the plumage colour of mule ducks in selected Tsaiya ducks may be simultaneously selected by traditional breeding. It also demonstrates the traditional breeding strategy for improving plumage colour of mule ducks is highly reliable.

\section{Conclusion}

The c.995G >A amino acid substitution in EDNRB2 gene of mule ducks has a significant association with white plumage. The current findings provide a novel insight into the relationship between the maternal $E D N R B 2$ gene polymorphism and plumage colour in intergeneric hybrid ducks.

\section{Authors' Contributions}

Conceptualization: YHY and MCC. Data curation: CWL, YHY and MCC. Analysis: CWL, YHY and MCC. Funding acquisition: MCC. Investigation: CWL, HHL, YHY and MCC. Methodology: YHY and MCC. Project administration: YHY and MCC. Resources: LYW, YYC, HCL and MCC. Supervision: HCL, HHL, YHY and MCC. Validation: HCL, HHL, YHY and MCC. Writing: YHY and MCC.

\section{Conflict of Interest Declaration}

The authors declare that they have no conflict of interest.

\section{References}

Bennett, D.C. \& Lamoreux, M.L., 2003. The color loci of mice-a genetic century. Pigment Cell Res. 16, 333-344.

Emaresi, G., Ducrest, A.L., Bize, P., Richter, H., Simon, C. \& Roulin, A., 2013. Pleiotropy in the melanocortin system: Expression levels of this system are associated with melanogenesis and pigmentation in the tawny owl (Strix aluco). Mol. Ecol. 22, 4915-4930.

Gong, Y., Yang, Q., Li, S., Feng, Y., Gao, C., Tu, G. \& Peng, X., 2010. Grey plumage colouration in the duck is genetically determined by the alleles on two different interacting loci. Anim. Genet. 41, 105-108.

Harris, M.L., Hall, R. \& Erickson, C.A., 2008. Directing pathfinding along the dorsolateral path - the role of EDNRB2 and EphB2 in overcoming inhibition. Development 135, 4113-4122.

Hauswirth, R., Haase, B., Blatter, M., Brooks, S.A., Burger, D., Drögemüller, C., Gerber, V., Henke, D., Janda, J., Jude, R., Magdesian, K.G., Matthews, J.M., Poncet, P.A., Svansson, V., Tozaki, T., Wilkinson-White, L., Penedo, M.C., Rieder, S. \& Leeb, T., 2012. Mutations in MITF and PAX3 cause 'splashed white' and other white spotting phenotypes in horses. PLOS Genetics 8, e1002653.

Kinoshita, K., Akiyama, T., Mizutani, M., Shinomiya, A., Ishikawa, A., Younis, H.H., Tsudzuki, M., Namikawa, T. \& Matsuda, Y., 2014. Endothelin receptor B2 (EDNRB2) is responsible for the tyrosinase-independent recessive white $(\mathrm{mo}(\mathrm{w}))$ and mottled (mo) plumage phenotypes in the chicken. PLOS ONE 9(1), e86361.

Krispin, S., Nitzan, E., Kassem, Y. \& Kalcheim, C., 2010. Evidence for a dynamic spatiotemporal fate map and early fate restrictions of premigratory avian neural crest. Development 137, 585-595.

Lecoin, L., Sakurai, T., Ngo, M.T., Abe, Y., Yanagisawa, M. \& Le Douarin, N.M., 1998. Cloning and characterization of a novel endothelin receptor subtype in the avian class. Proc. Natl. Acad. Sci. USA. 95, 3024-3029.

Lee, S.R. \& Kang, C.L., 1997. Improvement on percentage of white plumage in mule ducks. J. Taiwan Livest. Res. 30 , 293-299.

Li, L., Li, D., Liu, L., Li, S., Feng, Y., Peng, X. \& Gong, Y., 2015. Endothelin receptor B2 (EDNRB2) gene is associated with spot plumage pattern in domestic ducks (Anas platyrhynchos). PLoS One 10(5), e0125883.

Li, S., Wang, C., Yu, W., Zhao, S. \& Gong, Y., 2012. Identification of genes related to white and black plumage formation by RNA-Seq from white and black feather bulbs in ducks. PLoS One 7(5), e36592.

Mills, M.G. \& Patterson, L.B., 2009. Not just black and white: Pigment pattern development and evolution in vertebrates. Semin. Cell Dev. Biol. 20, 72-81.

Miwa, M., Inoue-Murayama, M., Kobayashi, N., Kayang, B.B., Mizutani, M., Takahashi, H. \& Ito, S., 2006. Mapping of panda plumage colour locus on the microsatellite linkage map of the Japanese quail. BMC Genet. 7, 2.

Miwa, M., Inoue-Murayama, M., Aoki, H., Kunisada, T., Hiragaki, T., Mizutani, M. \& Ito, S., 2007. Endothelin receptor B2 (EDNRB2) is associated with the panda plumage colour mutation in Japanese quail. Anim. Genet. 38, 103-108.

Nataf, V., Lecoin, L., Eichmann, A. \& Le Douarin, N.M., 1996. Endothelin-B receptor is expressed by neural crest cells in the avian embryo. Proc. Natl. Acad. Sci. USA. 93, 9645-9650.

Nitzan, E., Krispin, S., Pfaltzgraff, E.R., Klar, A., Labosky, P.A. \& Kalcheim, C., 2013. A dynamic code of dorsal neural tube genes regulates the segregation between neurogenic and melanogenic neural crest cells. Development 140, 2269-2279.

Pla, P. \& Larue, L., 2003. Involvement of endothelin receptors in normal and pathological development of neural crest cells. Int. J. Dev. Biol. 47, 315-325.

Pla, P., Alberti, C., Solov'eva, O., Pasdar, M., Kunisada, T. \& Larue, L., 2005. Ednrb2 orients cell migration towards the dorsolateral neural crest pathway and promotes melanocyte differentiation. Pigment Cell Res. 18, 181-187.

Roulin, A. \& Ducrest, A.L., 2013. Genetics of colouration in birds. Semin. Cell Dev. Biol. 24, 594-608.

Tu Y.C., Wei L.Y., Chang Y.Y., Liu H.C., Lee H.H., Yu Y.H. \& Chen M.C., 2019. Effects of melanocortin 1 receptor (MC1R) gene polymorphisms on plumage color in mule ducks. R. Bras. Zootec. 48, e20180180.

Wu, N., Qin, H., Wang, M., Bian, Y., Dong, B., Sun, G., Zhao, W., Chang, G., Xu. Q. \& Chen, G., 2017. Variations in endothelin receptor B subtype 2 (EDNRB2) coding sequences and mRNA expression levels in 4 Muscovy duck plumage colour phenotypes. Brit. Poult. Sci. 58,116-121. 